\title{
Keefektifan Implementasi Metode Certainty Factor Untuk Diagnosa Gangguan Perkembangan Anak Retardasi Mental
}

\author{
Valerian Hendri Yono*1, Halim Agung ${ }^{2}$ \\ 1,2 Jurusan Teknik Informatika, FTD UBM, Jakarta \\ ${ }^{1,2}$ Universitas Bunda Mulia; Jl. Lodan Raya No.2, (021) 692-9090 \\ ${ }^{*}$ hagung@bundamulia.ac.id
}

\begin{abstract}
Abstrak-- Anak-anak merupakan masa fase yang paling rentan dan sangat perlu diperhatikan tahapan perkembangannya, oleh sebab itu sangat diperlukan perhatian orang tua untuk memperhatikan perkembangan mereka. Untuk membantu orang tua dalam memperhatikan anaknya maka diperlukan suatu metode yang dapat diterapkan pada aplikasi kecerdasan buatan. Aplikasi ini dibuat dengan menggunakan metode Certainty Factor, dimana nilai kemungkinan gangguan yang dialami anak didapatkan dari gejala-gejala yang dialami anak. Hasil penelitian dari aplikasi ini menunjukkan bahwa aplikasi ini efektif dalam menentukan gangguan perkembangan anak serta memberikan saran yang dianjurkan terhadap gangguan tersebut berdasarkan gejala-gejala yang sebelumnya dipilih oleh user dengan tingkat akurasi persentase hasil kebenaran sebesar $\mathbf{7 1 , 4 3 \%}$ yang didapat dari hasil pengujian aplikasi oleh pakar psikolog anak..
\end{abstract}

Kata Kunci- certainty factor, retardasi mental, artificial Intelligence

\section{Pendahuluan}

Fase yang paling rawan dan sangat perlu diperhatikan tahapan perkembangannya adalah masa anak-anak. Badan Kesehatan Dunia (WHO) memperkirakan jumlah anak retardasi mental yang ada di Indonesia sekitar 7-10\% dari total jumlah anak yang ada di Indonesia. Pada tahun 2003 jumlah anak retardasi mental 679.048 atau $21,42 \%$, dengan perbandingan laki-laki $60 \%$ dan perempuan $40 \%$. Dengan kategori retardasi mental sangat berat (Idiot) $25 \%$, kategori berat $2,8 \%$, retardasi mental cukup berat (Imbisil debil profound) $2,6 \%$, dan retardasi mental ringan 3,5\%[1]. Karakteristik dari anak yang mengalami gangguan perkembangan anak biasanya tidak bisa diam, selalu gelisah, suka membuat keributan, dan beraktifitas berlebihan. Hal ini membuat dampak yang buruk bagi perkembangan sosial anak tersebut. Oleh karena itu dibangunlah suatu aplikasi yang dapat membantu untuk menentukan jenis gangguan perkembangan anak dalam hal ini adalah menggunakan metode Certainty Factor yang diukur keefektifannya dalam mendiagnosa masalah retardasi mental ini. Certainty Factor dalam penelitian yang dilakukan oleh Jadiaman juga digunakan untuk mendiagnosa seseorang yang menderita penyakit jantung dengan kondisi apabila seorang dokter atau pakar tidak ada dengan mudah[2]. Certainty Factor yang juga dilakukan oleh Sukma Yoga Wirabuana membahas pendeteksian penyakit sistem saraf pusat manusia dengan menggunakan metode penelusuran yang digunakan adalah forward chaining dan metode Certainty Factor untuk menghitung besarnya derajat kepercayaan. Informasi yang dihasilkan dari sistem ini adalah nama penyakit, gejala, penyebab, solusi serta kepastian dalam bentuk nilai probabilitas kepastian pakar[3]. Certainty Factor yang diterapkan dalam penelitian yang dilakukan oleh Poni Wijayanti digunakan untuk mampu mendiagnosa jenis penyakit stroke yang berdasarkan gejala yang dimasukkan dan dapat memberikan informasi tentang penyakit yang terdiagnosa[4].

\section{Metode PENELITIAN}

Metode yang digunakan dalam penelitian ini adalah Metode dengan model Waterfall. Untuk data yang diperlukan dalam penelitian ini adalah daftar penyakit beserta gejalanya dan daftar penyakit beserta saran yang dihimbaukan. Data yang disebutkan didapatkan dengan observasi ke rumah sakit dan studi pustaka. Untuk daftar penyakit beserta gejalanya dibagi menjadi retardasi mental ringan, sedang, berat dan sangat berat. Aplikasi ini dibangun untuk membantu orang tua dalam mendiagnosa masalah retardasi mental yang terjadi pada anak dari orang tua tersebut yang digambarkan pada Use Case pada Gambar 1 dimana orang tua dapat melakukan diagnosa pada aplikasi dan melihat pustaka atau info mengenai retardasi mental.

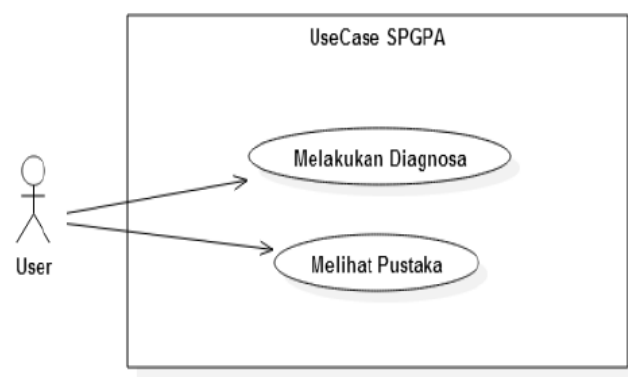

Gambar 1. Use Case Diagram 
Kemudian untuk menjelaskan proses alur kerja operasional secara langkah demi langkah dari komponen suatu sistem digambarkan pada activity diagram yang dimana yang dijelaskan pada gambar 2 adalah activity diagram dalam melakukan diagnosa.

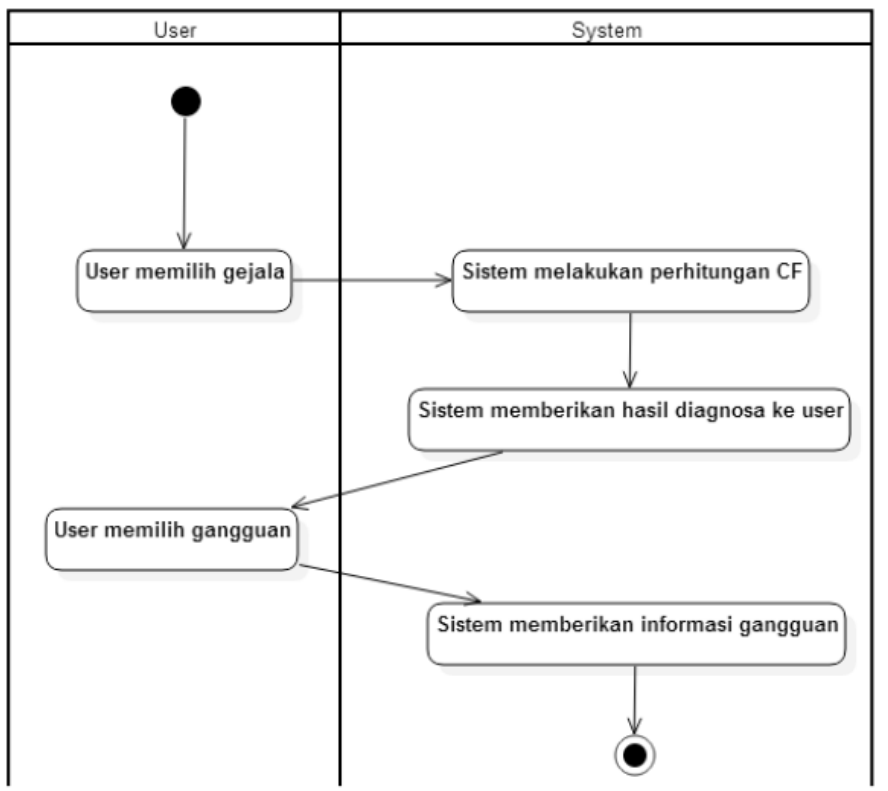

Gambar 2. Activity Diagram Melakukan Diagnosa

Gambar 2 menjelaskan bahwa tahapan pertama kali aplikasi nantinya berjalan adalah orang tua memilih gejala - gejala yang diberikan kemudian setelah itu sistem melakukan perhitungan Certainty Factor dan memberikan hasil diagnosa nya ke orang tua. Setelah itu orang tua akan memilih gangguan yang terjadi akibat gejala tersebut dan sistem akan memberikan informasi gangguan. Kemudian untuk menggambarkan kejelasan perilaku pada proses berjalannya sistem maka digambarkan pada sequence diagram yang terdapat pada gambar 3 .

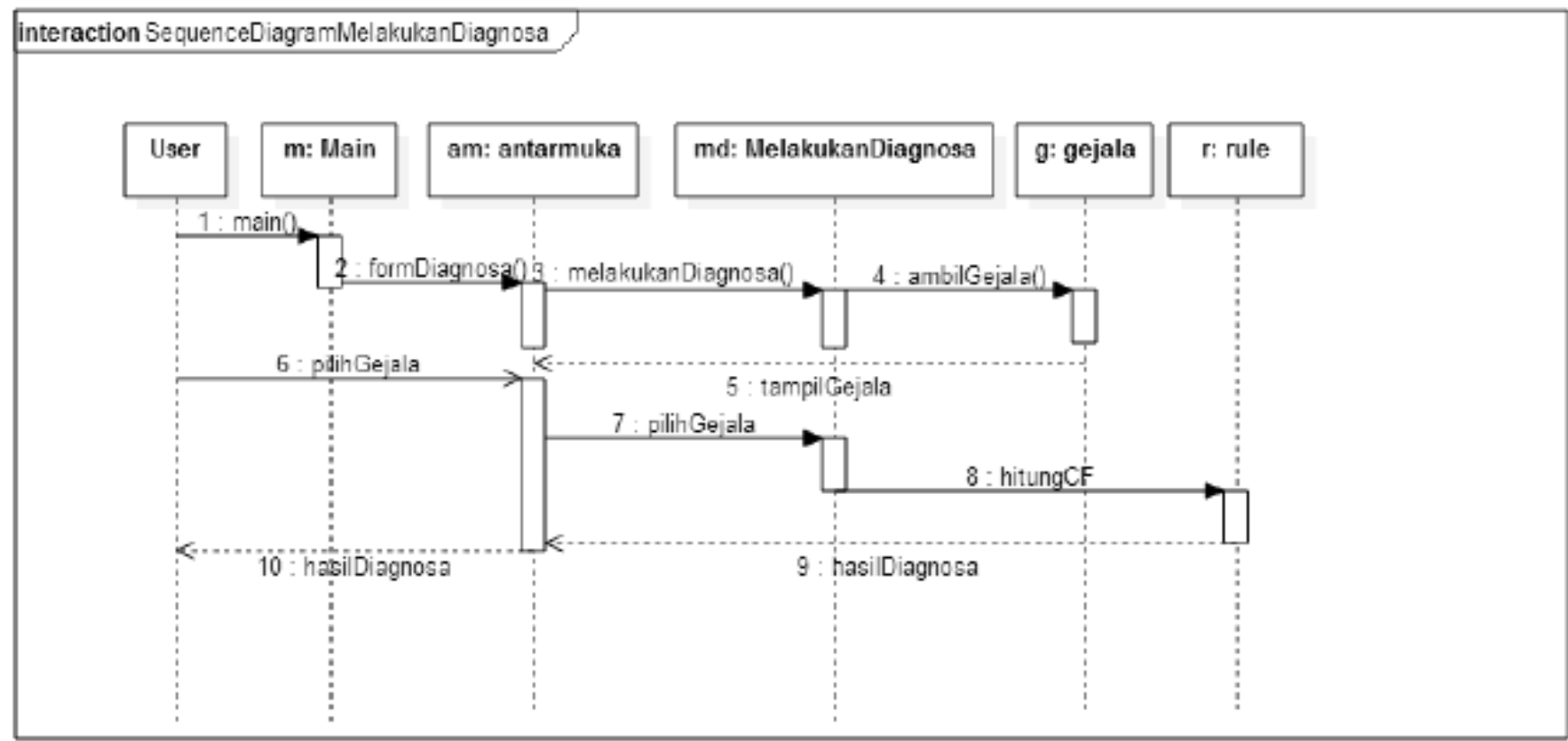

Gambar 3. Sequence Diagram Melakukan Diagnosa 
Untuk menjelaskan urutan instruksi yang terjadi pada saat menggunakan aplikasi yang akan dibuat maka peneliti menggunakan flowchart. Flowchart yang ditampilkan adalah flowchart aplikasi diagnosa retardasi mental anak yang ditampilkan pada gambar 4 .

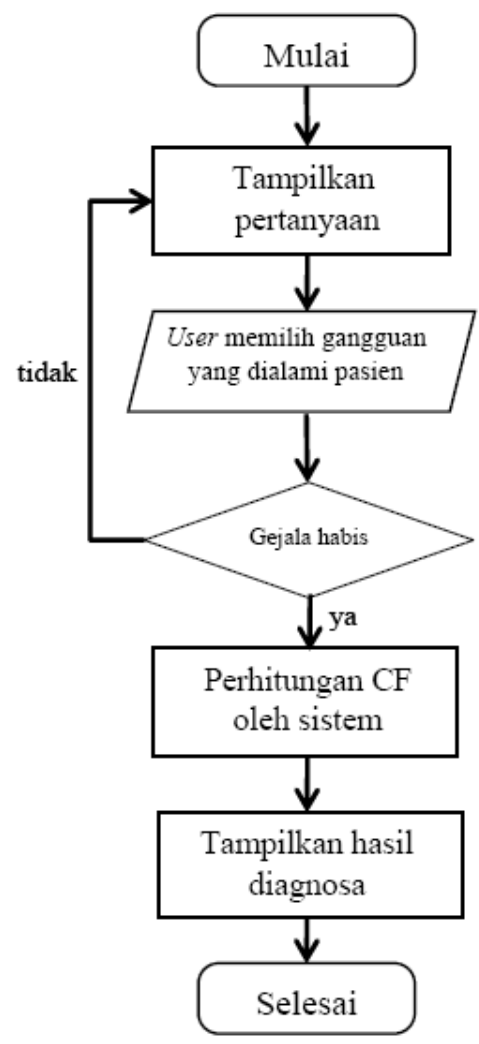

Gambar 4. Flowchart Aplikasi Diagnosa Retardasi Mental

Kemudian untuk menampung data yang dibutuhkan dalam aplikasi retardasi mental anak maka Entity Relationship Diagram (ERD) digunakan untuk membantu dalam pembuatan database pada aplikasi. Berikut ERD yang ditampilkan pada gambar 5 .

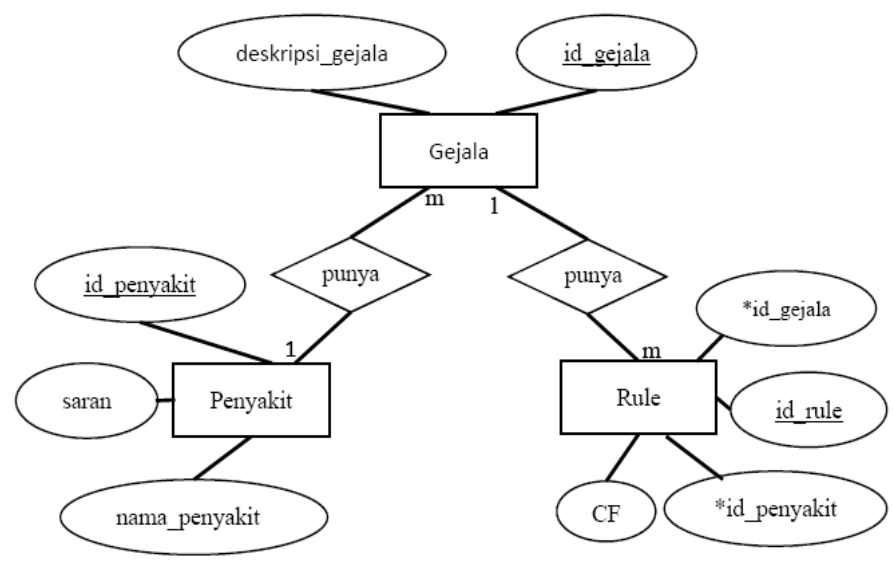

Gambar 5. ERD Aplikasi Retardasi Mental
Kemudian untuk metode Certainty Factor yang digunakan pada aplikasi retardasi mental anak nantinya disesuaikan dengan gejala yang dipilih user pada form diagnosa. Sistem akan membaca hubungan gejala yang dipilih oleh user dengan penyakit apa saja yang mempunyai gejala yang sesuai. Setelah itu sistem akan menampilkan diagnosa penyakit yang memiliki nilai keyakinan yang paling tinggi. Dalam menghitung Certainty Factor penyakit yang memiliki gejala yang lebih dari satu dapat menggunakan Certainty Factor kombinasi yaitu $\mathrm{CF}(\mathrm{CF} 1 \mathrm{CF} 2)=\mathrm{CF} 1+\mathrm{CF} 2 *(1-\mathrm{CF} 1)$ dengan $\mathrm{CF}(\mathrm{CF} 1 \mathrm{CF} 2)$ adalah hipotesis hasil dari perhitungan kepastian atas gejala terhadap penyakit yang merupakan hipotesis sementara apabila gejala lebih dari 2 dan $\mathrm{CF} 1$ serta $\mathrm{CF} 2$ adalah nilai kepastian atas gejala 1 dan 2 .

Berikut contoh perhitungan $\mathrm{CF}$ pada diagnosa penyakit gangguan perkembangan anak dengan masukkan gejala seperti pada tabel 1 .

Tabel 1. Contoh Masukkan Gejala Yang Diderita Pasien

\begin{tabular}{|c|c|}
\hline No & Gejala \\
\hline 1 & IQ antara 50-70 \\
\hline 2 & $\begin{array}{r}\text { Terbiasa melakukan komunikasi dalam } \\
\text { rutinitas sehari - hari }\end{array}$ \\
\hline 3 & $\begin{array}{c}\text { Bisa melakukan sebagian aktivitas merawat } \\
\text { diri meski perlu arahan dari orang lain }\end{array}$ \\
\hline
\end{tabular}

Berikut daftar penyakit yang memiliki gejala pada tabel 1 dari gejala yang dimasukkan oleh user beserta dengan perhitungannya :

\section{A. Retardasi mental ringan}

1) IQ antara $50-70, \mathrm{CF}=0.7=\mathrm{CF} 1$

2) Terbiasa melakukan komunikasi dalam rutinitas sehari - hari

$\mathrm{CF}=0.4=\mathrm{CF} 2$

$\mathrm{CF}(\mathrm{CF} 1 \mathrm{CF} 2)=0.7+0.4 *(1-0.7)=0.82$

Nilai $\mathrm{CF}$ retardasi mental ringan $=0.82$

\section{B. Retardasi mental sedang}

1) Bisa melakukan sebagian aktifitas merawat diri meski perlu arahan dari orang lain, $\mathrm{CF}=0.5$ dimana nilai $\mathrm{CF}$ autis $=0.5$

Dari perhitungan diatas, jika hanya ada 1 gejala yang masuk kedalam salah satu kriteria penyakit maka CF1 lah yang diambil untuk mewakili kepastian dari penyakit yang bersangkutan berdasarkan gejala yang dimasukkan oleh user sedangkan jika gejala yang masuk dalam suatu kriteria penyakit lebih dari satu maka akan dihitung menggunakan rumus $\mathrm{CF}$ kombinasi sehingga menghasilkan nilai kepastian untuk tiap penyakit yang memiliki gejala sesuai dengan masukkan gejala yang diderita pasien yaitu retardasi mental 
ringan $=0.82$ dan autis 0.5 . Dengan hasil perhitungan yang sudah dilakukan maka nilai kepastian pasien menderita gangguan retardasi mental ringan adalah yang terbesar yaitu 0.82 .

\section{HASIL DAN PEMBAHASAN}

Hasil implementasi dari analisis yang sudah dilakukan adalah suatu aplikasi retardasi mental. Untuk tampilan pertama yaitu halaman diagnosa yang akan menampilkan gejala yang diambil dari database terdapat pada gambar 6.

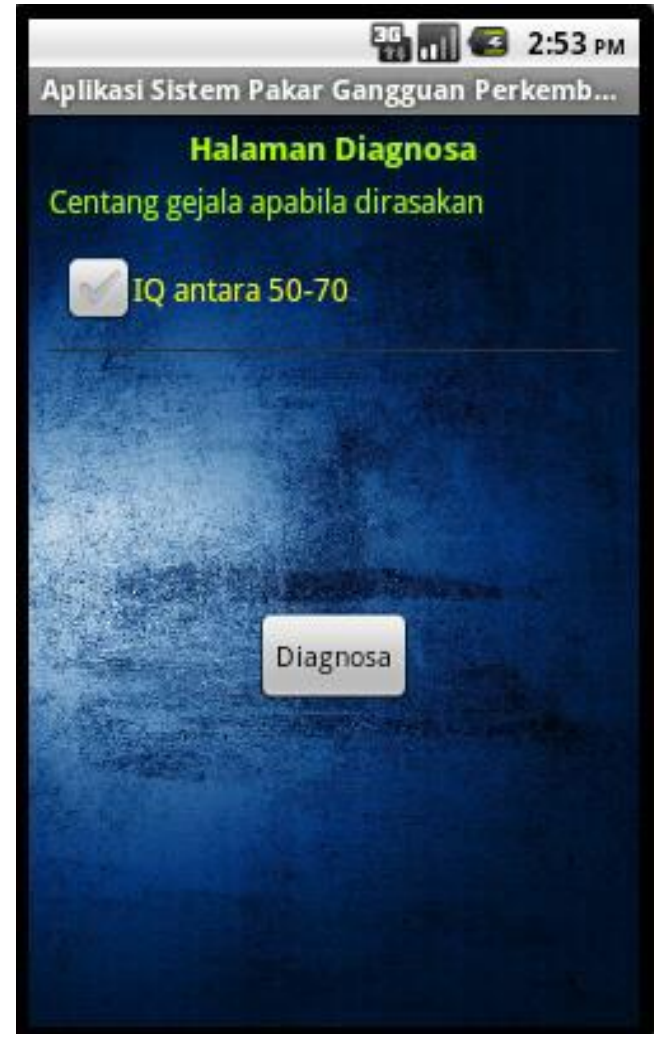

Gambar 6. Tampilan halaman diagnosa

Pada gambar 6 pengguna memilih gejala yang dialami oleh anak, pengguna dapat mencentang gejala apabila anak mengalami gejala yang diberikan, apabila anak tidak mengalami gejala yang diberikan sistem, pengguna tidak harus mencentang gejala tersebut kemudian menekan button Diagnosa.

Kemudian setelah user memilih gejala-gejala yang ditampilkan pada halaman diagnosa maka aplikasi akan menampilkan hasil perhitungan diagnosa seperti pada gambar 7.

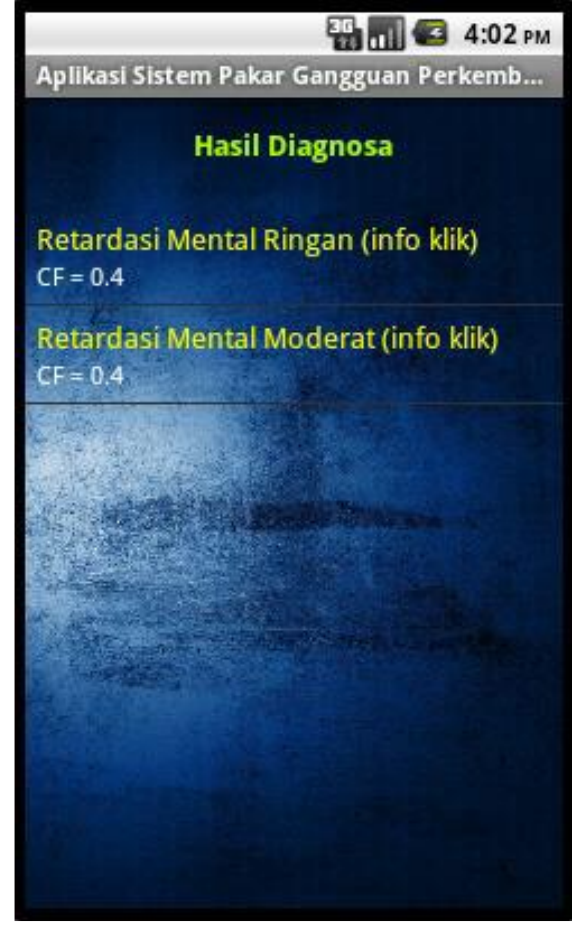

Gambar 7. Tampilan perhitungan hasil diagnose

Pada gambar 7 aplikasi akan menampilkan kemungkinan gangguan perkembangan yang dialami oleh anak berdasarkan perhitungan nilai CF yang terbesar (CF Maksimum) kemudian untuk mengetahui informasi gangguan perkembangan yang kemungkinan dialami anak dapat dilakukan dengan memilih pada nama gangguan tersebut yang ditampilkan pada gambar 8 .

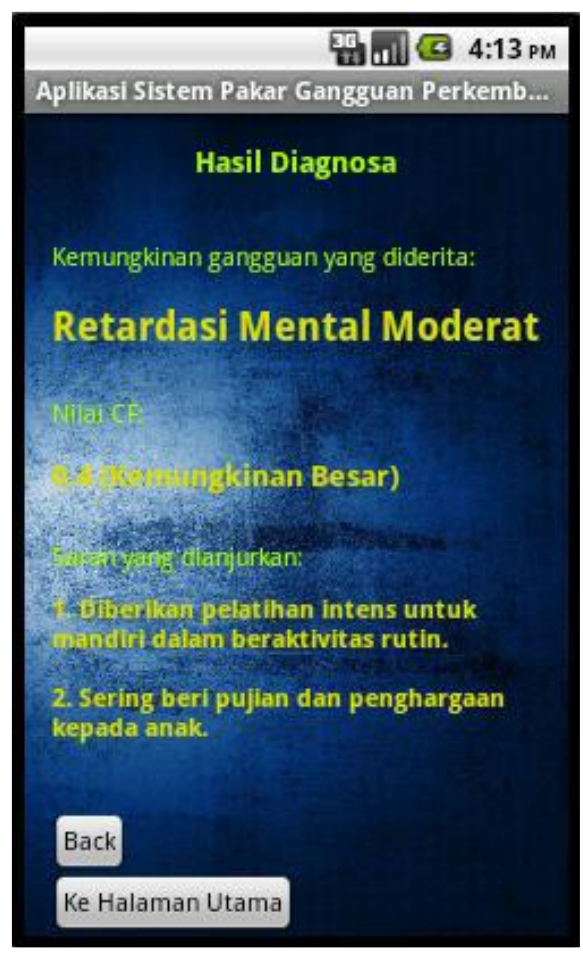

Gambar 8. Tampilan hasil diagnosa beserta saran yang dianjurkan 
Gambar 8 akan menampilkan kemungkinan gangguan perkembangan yang dialami oleh anak, besar nilai $\mathrm{CF}$ berdasarkan perhitungan diagnosa, beserta saran yang dianjurkan. Kemudian mengenai metode Certainty Factor yang digunakan dibuat dengan tahapan membuat pseudocode terlebih dahulu yang ditampilkan pada gambar 9 .

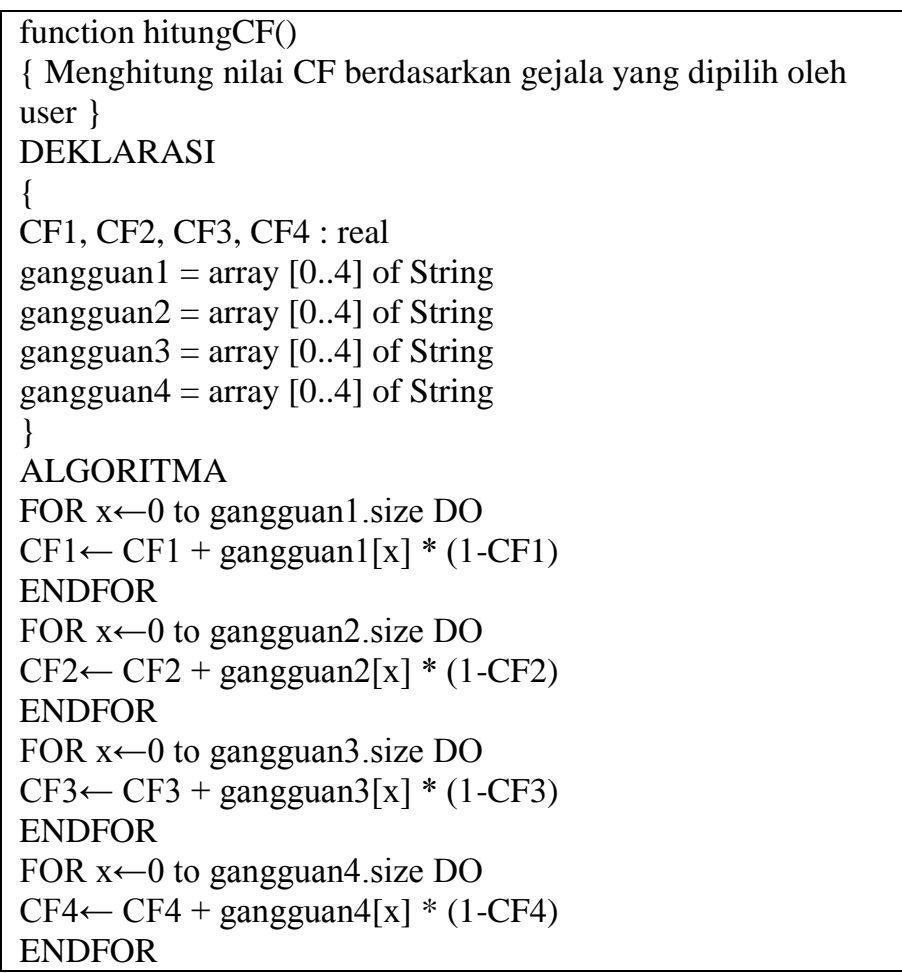

Gambar 9. Pseudocode metode certainty factor

Kemudian dari pseudocode pada gambar 9 lah aplikasi retardasi mental anak dibuat suatu aplikasi dalam penelitian ini. Setelah aplikasi dibuat kemudian dilakukan pengujian yang menguji efektif atau tidaknya metode Certainty Factor pada aplikasi retardasi mental anak yang dilakukan oleh pakar psikolog anak yang menggunakan aplikasi retardasi mental anak. Hasil pengujian ditampilkan pada tabel 2.

Tabel 2. Tabel pengujian oleh pakar

\begin{tabular}{|c|c|c|c|c|}
\hline \multirow[b]{2}{*}{ No } & \multirow[b]{2}{*}{ Gejala yang dipilih } & \multirow{2}{*}{$\begin{array}{c}\text { Hasil } \\
\text { diagnosa }\end{array}$} & \multicolumn{2}{|c|}{ Hasil pengujian } \\
\hline & & & Sesuai & $\begin{array}{l}\text { Tidak } \\
\text { sesuai }\end{array}$ \\
\hline 1 & 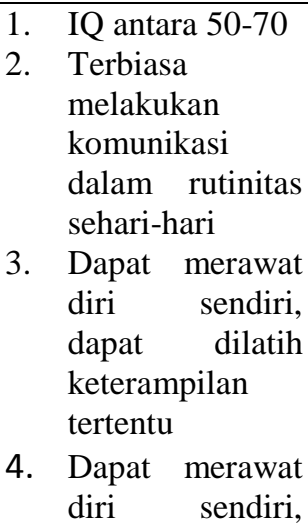 & $\begin{array}{l}\text { Retardasi } \\
\text { mental } \\
\text { ringan }\end{array}$ & $\mathrm{v}$ & \\
\hline
\end{tabular}

\begin{tabular}{|c|c|c|c|c|c|}
\hline & & $\begin{array}{l}\text { dapat dilatih } \\
\text { keterampilan } \\
\text { tertentu. }\end{array}$ & & & \\
\hline 2 & $\begin{array}{l}1 . \\
2 . \\
3 . \\
3 . \\
4 .\end{array}$ & $\begin{array}{l}\text { IQ antara } 35-55 \\
\text { Bisa diajak } \\
\text { berkomunikasi } \\
\text { meskipun butuh } \\
\text { usaha untuk } \\
\text { mendapatkan } \\
\text { perhatiannya } \\
\text { Bisa melakukan } \\
\text { sebagian } \\
\text { aktivitas diri } \\
\text { merawat dari } \\
\text { meski perlu } \\
\text { arahan } \\
\text { orang lain } \\
\text { Mampu } \\
\text { melakukan } \\
\text { aktivitas } \\
\text { calistung dengan } \\
\text { sedikit bantuan }\end{array}$ & $\begin{array}{l}\text { Retardasi } \\
\text { mental } \\
\text { moderat }\end{array}$ & $\mathrm{V}$ & \\
\hline 3 & $\begin{array}{l}1 . \\
2 .\end{array}$ & $\begin{array}{l}\text { IQ antara } 20-40 \\
\text { Perlu latihan } \\
\text { yang cukup } \\
\text { lama untuk } \\
\text { berbicara, } \\
\text { seringkali gagal } \\
\text { untuk } \\
\text { mendapatkan } \\
\text { perhatiannya } \\
\text { apabila diajak } \\
\text { berkomunikasi. } \\
\text { Butuh } \\
\text { pendampingan } \\
\text { hampir sebagian } \\
\text { besar dalam } \\
\text { aktivitas } \\
\text { mengarahkan } \\
\text { diri }\end{array}$ & $\begin{array}{l}\text { Retardasi } \\
\text { mental berat }\end{array}$ & $\mathrm{V}$ & \\
\hline 4 & $\begin{array}{l}1 . \\
2 .\end{array}$ & $\begin{array}{l}\text { IQ dibawah } 20 \\
\text { Sangat jarang } \\
\text { hingga tidak } \\
\text { pernah } \\
\text { berkomunikasi } \\
\text { Membutuhkan } \\
\text { pertolongan } \\
\text { orang lain secara } \\
\text { penuh dalam } \\
\text { merawat diri } \\
\end{array}$ & $\begin{array}{l}\text { Retardasi } \\
\text { mental } \\
\text { sangat berat }\end{array}$ & $\mathrm{V}$ & \\
\hline 5 & & $\begin{array}{l}\text { IQ antara } 50-70 \\
\text { Bisa diajak } \\
\text { berkomunikasi } \\
\text { meskipun butuh } \\
\text { usaha untuk } \\
\text { mendapatkan } \\
\text { perhatiannya }\end{array}$ & $\begin{array}{l}\text { Retardasi } \\
\text { mental } \\
\text { moderat }\end{array}$ & & $\mathrm{V}$ \\
\hline
\end{tabular}




\begin{tabular}{|c|c|c|c|c|}
\hline & 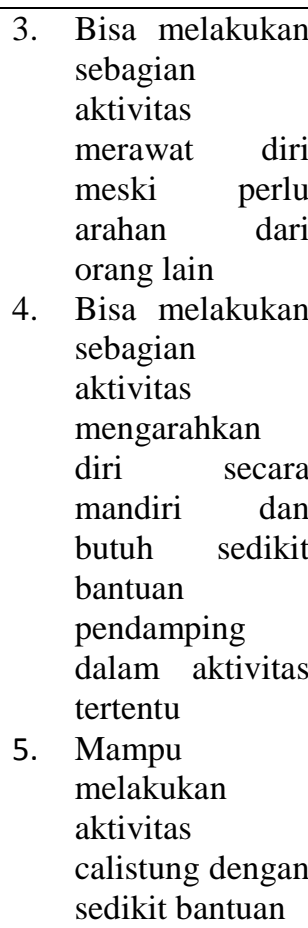 & & & \\
\hline 6 & $\begin{array}{l}\text { 1. } \begin{array}{l}\text { Terbiasa } \\
\text { melakukan } \\
\text { komunikasi } \\
\text { dalam rutinitas }\end{array} \\
\text { sehari-hari } \\
\text { 2. Dapat merawat } \\
\text { diri sendiri, } \\
\text { dapat dilatih } \\
\text { keterampilan } \\
\text { tertentu. } \\
\text { 3apat belajar } \\
\text { membaca, } \\
\text { menulis dan } \\
\text { berhitung } \\
\text { sederhana }\end{array}$ & $\begin{array}{l}\text { Retardasi } \\
\text { mental } \\
\text { ringan }\end{array}$ & & $\mathrm{V}$ \\
\hline 7 & $\begin{array}{ll}\text { 1. } & \text { IQ antara } 50-70 \\
\text { 2. } & \text { Terbiasa } \\
& \text { melakukan } \\
& \text { komunikasi } \\
& \text { dalam rutinitas } \\
& \text { sehari-hari } \\
\text { 3. } & \text { Bisa melakukan } \\
& \text { sebagian } \\
& \text { aktivitas } \\
\text { merawat diri } \\
\text { meski perlu }\end{array}$ & $\begin{array}{l}\text { Retardasi } \\
\text { mental } \\
\text { ringan }\end{array}$ & $\mathrm{V}$ & \\
\hline
\end{tabular}

\begin{tabular}{|l|l|l|l|l|}
\hline arahan dari & & & \\
orang lain & Sulit atau \\
seringkali tidak & & & \\
mampu & & & \\
melakukan & & & \\
aktivitas & & & \\
calistung & & & \\
\hline
\end{tabular}

Berdasarkan pengujian yang dilakukan oleh pakar pada Tabel 2, dapat ditarik kesimpulan bahwa tingkat persentase keefektifan hasil kebenaran diagnosa aplikasi terhadap gangguan sebesar $5 / 7 * 100 \%=71.43 \%$.

\section{KESIMPULAN}

Berdasarkan hasil yang didapat dalam penelitian ini, maka dapat ditarik kesimpulan bahwa metode Certainty Factor memiliki keefektifan sebesar $71.43 \%$ dalam hal mendiagnosa retardasi mental anak berdasarkan gejala yang di masukkan oleh user untuk mengetahui kemungkinan gangguan perkembangan yang dialami anak.

\section{SARAN}

Aplikasi ini diharapkan dapat dibangun dengan menggunakan algoritma lainnya maupun modifikasi dari beberapa algoritma sehingga dapat meningkatkan keakuratan dan keefektifan hasil diagnosa retardasi mental anak.

\section{DAFTAR PUSTAKA}

[1] Kementerian Kesehatan RI, 2014, Situasi Penyandang Disabilitas, Buletin Jendela Data dan Informasi Kesehatan, vol 2, ISSN 2088-270X, 2014.

[2] Jadiaman Parhusip, Viktor H. Pranatawijaya dan Dwimaryuga Putrisetiani. 2012. Sistem Pakar Diagnosa Penyakit Jantung Menggunakan Metode Certainty Factor Berbasis Web. Prosiding Seminar Nasional Informatika 2012, 1979-2328.

[3] Wirabuana, Sukma Yoga. 2011. Sistem Pakar Diagnosa Penyakit Pada Sistem Saraf Pusat Manusia (Skripsi S-1). Yogyakarta. Universitas Ahmad Dahlan.

[4] Poni Wijayanti dan Abdul Fadlil. 2014. Sistem Pakar Mendiagnosa Jenis Penyakit Stroke Menggunakan Metode Certainty Factor. Jurnal Sarjana Teknik Informatika. Vol 2. No 1, eISSN: 2338-5197. 